\title{
FULL RESERVE REQUIREMENT BANKING SYSTEM FOR THE COMMUNITY ECONOMIC SUSTAINABILITY
}

\author{
Lukertina Sihombing, Eko Tama Putra Saratian, Mochamad Soelton, Dudi Permana, and Noermijati \\ Universitas Mercu Buana Jakarta, Indonesia \\ Universitas Brawijaya, Indonesia.
}

\begin{abstract}
This is a community service related to the development of economic society through socialization on one of the three main pillars and principle in the economics and financial problems. Nowadays, people in the world have begun to care about the dangers of three pillars and its impact on the economy. They are interest, fiat money and fractional reserve requirement in the banking system. Ironically, there are still many ordinary people do not understand the general rules of the fractional reserve requirement in the banking system. In returning the economic and monetary to riba-free system, it is necessary to learn deeply about this subject. For this reason, there is a need for socialization to the wider community to increase good understanding of the three pillars, especially about the fractional reserve requirement in the banking system. This community service is expected to the community get finance literacy well and certainly can be considered in family financial planning.
\end{abstract}

Keywords: Fiat Money, Fractional Reserve Requirement, Interest, Riba, Sustainable Finance

\section{INTRODUCTION}

Nowadays, some people in the world have begun to care about the dangers of the three main pillars and their impact on the economy. One of them is about the fractional reserve requirement in the banking system. The failure of the current economic and monetary system is caused by riba of fractional reserve requirement in the banking system activity. According to the perspective, Islam always encourages the practice of real assets and forbids illusionary assets. Ironically, there are still many ordinary people do not understand the general rules of the fractional reserve requirement in the banking system.

Basically, people without knowledge are sentient and ignorant creatures as the word of Allah Subhanahu Wa Ta'ala "Verily, we have revealed the message to the heavens, the earth and the mountains, then all are reluctant to assume that mandate and they are worried that they will betray it, and be endured. that mandate by humans. Indeed, man is very wrong and very ignorant "(Al-Qur'an, Al-Ahzab: 72). Humans have turbulent passions, always feel lacking and never feel satisfied, according to their character and characteristics. Thus, halal transactions are no longer the main goal because they are often associated with minimal profits, a long and difficult process to obtain. This is also in line with the words of the Prophet Shallallahu 'Alaihi Wasallam, from Abu Hurairah Radhiyallahu' Anhu, that he Shallallahu 'Alaihi Wasallam said "there will come a time to mankind, they will no longer care about how to obtain wealth, whether through lawful means. or in an unlawful way "(HR. Bukhari).

Rasulullah Shallallahu 'Alaihi Wasallam has also conveyed threats to those who eat illicit wealth. He Shallallahu "Alaihi Wasallam said," actually will not enter the paradise of meat that grows from illicit wealth. Hell is more appropriate for him "(HR Ahmad and Ad-Darimi). Sustenance must come from a halal source and the purpose of use must also be channeled to those who do not violate the Shari'a, as the words of the Prophet Shallallahu 'Alaihi Wasallam "will not shift the footprints of a servant on the Day of Resurrection, until he is asked about four cases, (ie): about: his age for what he spent, about his body for what he used, about his wealth where he got it and where he put it, and about his knowledge, what he had practiced "(HR. At-Tirmidzi and Ad-Darimi). Likewise from Jabir's Radhiyallahu 'Anhu, that the Prophet Shallallahu 'Alaihi Wasallam said: "Do not assume that your fortune is slow down. Truly, no one leaves this world, but after his income is complete. Look for fortune in a good way (by) taking the halal and leaving the haram matters "(HR Al-Hakim and Al-Baihaqi).

In this increasingly difficult life, there are indeed parties who do not care anymore about halal and illicit issues about something, one of them is in financial matters. This is because our lives, starting from school and the environment have been polluted in the influence of the Western system of secularism-capitalism. The family is the smallest organization but has a great impact for all its members, one of which is in the formation of a conscious and wise character in financial management. With this phenomenon, it is felt necessary to disseminate to the public about the ideal concept of the reserve in the banking system and its impact on the economy. It also teaches the public about good portfolio management and the use of banking product wisely. 


\section{LITERATURE REVIEW}

According to Ahmad and Ismail (2017), the use of full reserve system can attain the Maqasid Shariah to support the alternative banking system. Using the argument on fractional reserve system, discussion on the concept of full reserve system, analysis of the impacts of full reserve system and the support from Quran and Hadith, this study concludes that the injustice and riba' can be avoided under the full reserve system, hence, attaining the Maqasid Shariah. According to Chair (2014), riba is an addition to more than the original capital, riba transactions are often find in the debt transactions where creditors ask for additional capital from the original to the debtor. Riba is often also translated to mean additional money on capital obtained in a way that is prohibited by Shara ', either with a small additional amount or even with a large additional amount. Riba (interest) has become the fad of every conventional financial transaction. This is an idea postulated by the capitalist not minding its implication to the economy in as far as they are accumulating wealth out of it (Mohammad, 2016). Based on Laina (2015), fractional reserve banking system would lead to credit crunch or excessively volatile interest rates were found to be baseless.

Fractional reserve or commonly called the statutory reserve requirement is the minimum funds or deposits that must be maintained by banks in the form of current account balances placed at the Central Bank. The amount of fractional reserve is determined by the central bank based on the percentage of third party funds collected by banks. This partial reserve is required to meet the normal conditions of demand from depositors who withdraw their savings or deposits. In Indonesia, fractional Rupiah of conventional commercial banks is $6.5 \%$ form third party funds. For Sharia Commercial Banks and Sharia Business Units, total Rupiah fractional is $\%$ from total of funds. The amount of reserves is generally far below 100 percent. That is why it is called a fraction (fractional). If the Central Bank requires a FRR of 10 percent, then for a deposit of Rp. 100 million, it is necessary to provide at least a reserve of Rp. 10 million. With the rules, banks can freely lend the other 90 percent to customers or depositors in need. Logically there is nothing wrong with this rule. But in practice, fractional reserve regulations place banks indirectly as agents that influence and increase money supply. The depositor's customer (IDR100 in cash) recognizes his IDR100 in money, on the other hand the IDR100 in money has been channeled by $90 \%$ (IDR90 worth) to credit customers, and at the same time the credit customer also recognizes IDR90 of his money as his own money. In other words, the money in circulation currently becomes IDR100 (owned by depositors' customers) plus IDR90 (owned by credit customers) because both depositors and credit customers can simultaneously take and acknowledge their respective money, so that the money in circulation currently becomes IDR190 due to the fractional reserve system. In short, commercial banks, not just Central Banks, have participated in printing money.

\section{The Basic Fractional Reserve Banking Cycle}

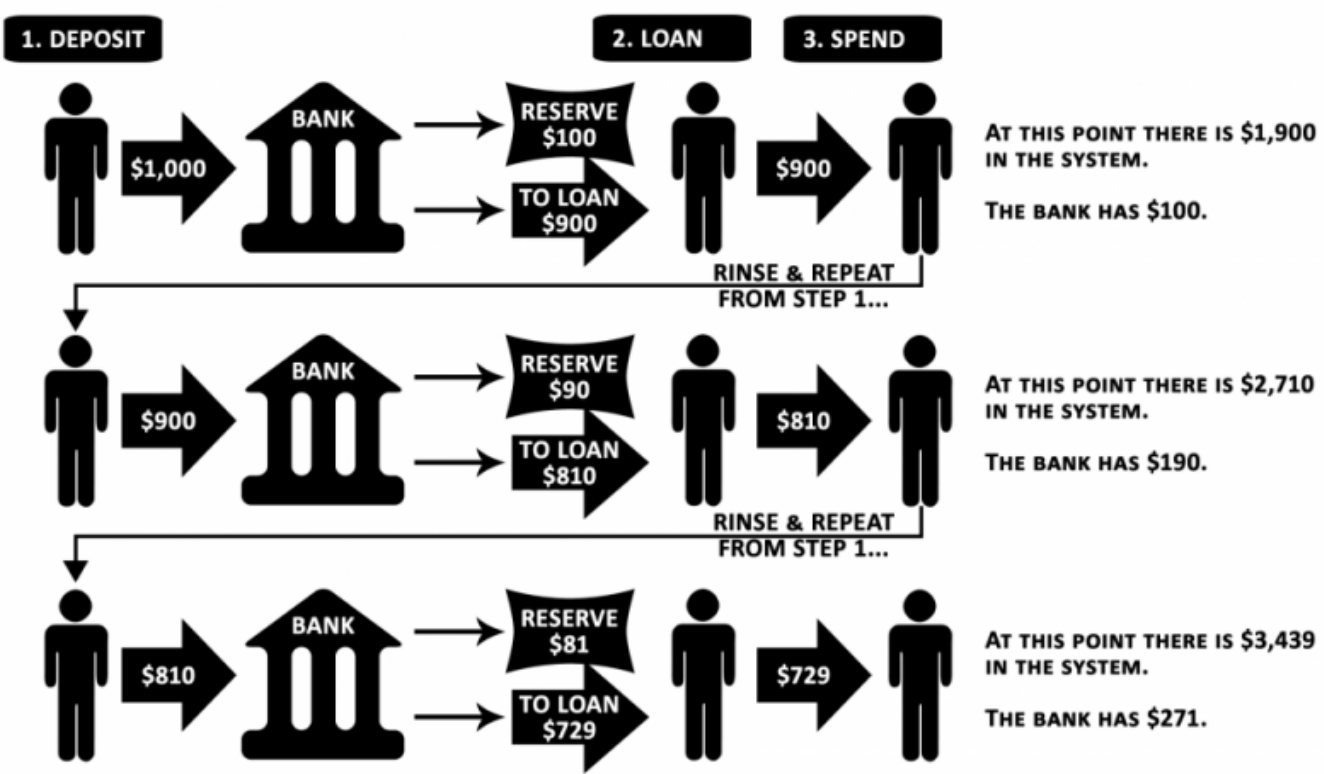

Figure 1. The Basic Fractional Reserve Banking Cycle

Sources: http://cynic.me 
According to Levrero and Deleidi (2017), money supply is mainly determined endogenously by the lending activity of commercial banks. Fractional reserve requirement in the banking system relates to riba system, because it increases money creation without the increase of the real sector. According to Ghofur (2016), the Qur'an itself has explained in detail the stages of the prohibition of riba. The first stage simply describes the negative elements in riba (Al-Qur'an, Ar-Ruum, $30: 39$ ). Then followed by the sign of forbidden riba with the delivery of condemnation of the Jews who practice riba (Al-Qur'an, An-Nisa 4 : 160-161). Next, the Qur'an explicitly forbids riba with the limitation of adh fan mudhā afan (Al-Qur'an, Ali Imron, $3: 130$ ) which is followed by a total prohibition of riba in various forms (Al-Qur'an, Al-Baqarah, $2: 275$ - 276).

\section{METHOD}

In this Community Service, the methods used are interactive lectures, discussion and question and answer. This lecture was packaged as a socialization activity held on March 14th, 2019 at $09.00-12.00$ at the RPTRA Kampung Baru, Jalan Teratai Kampung Baru RT. 009/010, Kelurahan, Kembangan Utara, Kecamatan Kembangan, Jakarta Barat, DKI Jakarta. This activity was attended by around of 50 students from Al-Washilah 1 Jakarta Vocational School.

The purpose of this activity is to provide socialization and counseling to get financial literacy early on in North Kembangan, Kembangan, West Jakarta. The objectives of this activity include: (a) increasing public understanding of the principles of muamalah and the sharia economic system, (b) understanding the prohibitions and negative impacts of riba on the economy, (c) providing an introduction to Islamic financial instruments as a solution in managing family finances and (d) teaches the public about good portfolio management and the use of banking product wisely.

\section{RESULT AND DISCUSSION}

Riba is considered by many as a trigger for the crisis. The main pillars of riba which are considered as the main causes of the crisis include; interest, fiat money and fractional reserve requirements in the banking system. These three pillars complement each other in creating money creation so that it increases money circulation without backing up gold or other real assets, which consequently causes inflation, damages the economy and the monetary system. Riba is the source of the problem of all problems. The majority of poverty occurs not because of the unavailability of jobs or low levels of education, far from that this is due to damage to the system resulting from the pillars of riba. The excessive exploitation of natural resources is also caused by the riba system, thus forcing developing countries to pay principal and interest loans with their natural resources. Riba also causes excessive human exploitation. They have to go the extra mile to pay debts, which in essence will never be paid-off at a macro level, because the majority of new money is created by credit activities in the banking system.

So do not be surprised if Allah Subhanahu Wa Ta'ala threatens the perpetrators of riba with such a heavy threat and a great sin, as he said:

"O you who believe, fear Allah and leave the rest of riba (that has not been collected) if you are a believer. So, if you don't work (leaving the rest of riba) then know that Allah and His Messenger will fight you. However, if you repent (of riba taking), then for you the subject of your treasure; you do not persecute nor are you persecuted" (Al-Qur'an, Al-Baqarah, 2: 278 - 279).

Furthermore, the Prophet Muhammad Shallallahu 'Alaihi Wasallam conveyed a threat to the perpetrators of riba in the following Hadiths:

From Abdullah bin Hanzhalah, that the Prophet Shallallahu 'Alaihi Wasallam said: "One dirham of riba money consumed by someone in a state of knowing that it is riba money is greater than adultery 36 times" (HR. Ahmad and Ath-Thabrani).

From Ibn Mas'ud, that the Prophet Shallallahu 'Alaihi Wasallam said: "Riba has 73 doors (levels), the lowest (sin) is the same as someone who commits adultery with his mother!" (HR. Al Hakim and Al Baihaqi).

From Aun bin Abi Juhaifa, "My father bought a slave whose job was to burn (to get dirty blood from the body), my father then destroyed the slave's cupping equipment. I asked father why he did it. My father replied, that the Prophet Shallallahu 'Alaihi Wasallam forbade receiving money from the transactions of blood, dogs, and 
kasab women slaves, he also cursed the work of tattoo makers and who asked for tattooing, receiving and giving riba and he cursed the makers of drawings" (HR. Bukhari).

"That he was blessed by two angels and they said, 'Come with us.' Until finally the two angels took him to a river of blood, in the river there was a person who was swimming. Meanwhile on the banks of the river there was one more person. When the person in the middle of the river wants to pull over, the man on the edge of the river throws his mouth with stones, until he returns to his original place (middle of the river of blood). Then the Prophet Shallallahu 'Alaihi Wasallam said:' I asked the two angels about the person who was in the river. 'They answered,' The person you came to, who swam in the river and then his mouth was gagged with stones, he is a usurious eater" (HR. Bukhari).

\section{CONCLUSION}

From the discussion above, some conclusions can be drawn that based on the verses of the Qur'an, the scholars agree that riba is something that is prohibited because it is considered very clear and chronologically the essence of the prohibition can be understood. On the other hand the Koran strongly encourages people to give alms, as his words in the Koran, Al-Baqarah, verse 276 "Allah destroy riba and fertilize alms".

Based on the discussion in the previous chapters, it can be concluded that this socialization is expected to increase public knowledge, including: (a) the realization of an increase in public understanding of the Muamalah Principles and Sharia Economic System, (b) the realization of an understanding of the prohibition and the negative impact of riba on the economy, (c) introduction and additional sharia financial literacy as a solution in family financial planning and (d) teaches the public about good portfolio management and the use of banking product wisely.

In addition, Prophet Muhammad Shallallaahu 'Alaihi Wasallam said: "Whoever sees (whatever is) munkar, then change it with his hands; and if he is unable to do so, then with his tongue; and if he is unable to do so, then with his heart; and that is the weakest faith" (HR. Muslim).

\section{REFERENCES}

Al-Qur'an, Al-Karim.

Ahmad, Zuriyati and Ismail, Abdul Ghafar. (2017). Full reserve system and the Maqasid Shariah. Journal of Emerging Economies and Islamic Research. Vol. 5, No. 2, 58-66.

Chair, Wasilul. (2014). Riba dalam Perspektif Islam dan Sejarah. Jurnal Iqtishadia. Vol. 1, No. 1 Edisi 1 98-113.

Ghofur, Abdul. (2016). Konsep Riba dalam Al-Qur'an. Jurnal Economica. Vol. VII, Edisi 1 1-26.

Hadits Bukhari, Muslim, Ahmad, Ad-Darimi, At-Tirmidzi, At-Thabrani, Al-Hakim, Al-Baihaqi.

Laina, Patrizio. (2015). Money Creation under Full-reserve Banking: A Stock-flow Consistent Model. Working Paper. No. 851, 1-32.

Levrero, Enrico Sergio and Deleidi, Matteo. (2017). The money creation process: A theoretical and empirical analysis for the US. MPRA Paper. No. 81970, 1-29.

Mohammad, Ibrahim. (2016). Riba (Usury); a Tool that should be Carved out of Financial Transactions. Turkish Journal of Islamic Economics. Vol. 3, No. 2, 13-24.

Soelton, Mochamad, Nugrahati, Tati, (2018). How Complaining Behaviors Effect on Coping Stress and Anxiety?. International Journal of Saudi Journal of Business and Management Studies (SJBMS). Vol. 3, No. 6. 623-628.

Soelton et al, (2019). Gender: Stress Levels on Performance in Modern Industry. International Journal Archives of Business Research (United Kingdom). Vol. 7, No 2, 72-81

Soelton et al, (2018). Toward The Best Strategy In Minimizing The Spread of Drug Users. International Conference on Community Development in Asia. Vol 1. No 1, 171-176 